\title{
PSYCHOMETRIKA V KUKURICI Stáž v Burosovom centre
}

\author{
SHOSHANA CHOVAN \\ Katedra psychologie, Fakulta sociálních studií $M U^{1}$
}

\begin{abstract}
Abstrakt: Článok je krátkou reportážou zo stáže v Burosovom centre pre testovanie na University of Nebraska v Lincolne. $V$ úvode je opísané zameranie Burosovho centra a jeho publikačná činnost', s podrobnejším popisom jednotlivých publikácií. Hlavná čast' článku približuje osobnú skúsenost's prácou v centre počas roka stráveného štúdiom na University of Nebraska a opisuje náplň práce študentského pracovníka. Článok d'alej hovorí o pomoci pri príprave Mental Measurement Yearbook a v závere sumarizuje históriu Burosovho centra a vyzdvihuje jeho prínos pre psychometriku.
\end{abstract}

Burosovo centrum pre testovanie je súčast'ou University of Nebraska v Lincolne. Jeho misiou je zdokonal'ovat' výskum a prax testovania, merania a diagnostiky v psychológii a príbuzných odboroch. Medzi hlavnú náplň práce centra patrí psychometrické poradenstvo a publikačná činnost'. Centrum vydáva tri periodické publikácie poskytujúce informácie o testoch - Mental Measurement Yearbook, Tests in Print a Pruebas Publicadas en Español.

Mental Measurement Yearbook je zbierkou recenzií komerčne dostupných testov v angličtine, vychádza každé tri roky a jej ciel’om je ponúknut' profesionálom množstvo podrobných informácií pri rozhodovaní, aký test použit'. Pred pár mesiacmi vyšlo jeho aktuálne, 20. vydanie. Tests in Print je obsiahlou bibliografiou všetkých komerčne dostupných testov $\mathrm{v}$ angličtine, poskytuje prehl'ad profesionálom z radov psychológov a pedagógov a vychádza každých 5 rokov, naposledy v roku 2016. Najmladšou publikáciou vychádzajúcou pod hlavičkou Burosu je Pruebas Publicadas en Español, ktorá poskytuje informácie o komerčných testoch, ktoré vychádzajú úplne alebo čiastočne v španielčine. Burosovo centrum zverejňuje recenzie testov aj online na svojich webstránkach. Jeho súčast'ou je aj knižnica s najväčšou zbierkou komerčných testov na svete, s takmer 8400 titulmi.

\footnotetext{
${ }^{1}$ Katedra psychologie, Fakulta sociálních studií Masarykovy univerzity, Joštova 10, 60200 Brno. Doručeno do redakce: 25. 10. 2017.
} 
O Burosovom centre som sa dozvedela náhodou od spolužiaka v deň, ked' som mala pohovor na štipendium do Nebrasky. Stalo sa potom jedným z kl'účových dôvodov, pre ktoré som sa rozhodla odíst' a predížit' si tak štúdium o d'alší rok.

Ked' som oslovovala Burosovo centrum s prosbou, či by som u nich nemohla stážovat', mala som pocit, že im s mojimi chabými psychometrickými znalost’ami nemám čo ponúknut'. Mala som len obrovskú motiváciu byt' súčast'ou niečoho, čo v našich končinách nemá obdobu. Hlavnú editorku Nancy Anderson a profesorku pre výskum Janet Carlson som však presvedčila, a tak som z nášho stretnutia odchádzala s ponukou práce.

Ako študentský pracovník bolo mojou náplňou práce spočiatku len pár hodín v týždni dohliadat' na knižnicu a poskytnút' informácie komukol'vek, kto by sa chcel príst' pozriet' na testy, alebo by zháňal informácie o ich psychometrických charakteristikách. Dostala som kl'úče od knižnice aj od regálov s tisíckami testov. Prvé týždne však nikto nechodil a ja som pochopila, že sa to pravdepodobne až do konca semestra nezmení. Nerozumela som, prečo do knižnice nikto nechodí - okrem testov tam bola aj zbierka kníh Oscara Burosa, mal'by a sochy jeho ženy Luelly, pôvodné vydania časopisov, niektoré aj 90 rokov staré, mnoho monografií a učebníc špecializovaných na testovanie v psychológii, vzdelávaní a neurovedách. Na Univerzite $\mathrm{v}$ Nebraske pritom boli tisíce študentov psychológie a pedagogiky a knižnica bola dostupná všetkým.

Vel'mi skoro som sa začala dožadovat' nejakej roboty navyše. Našt’astie mali v Burose plné ruky práce s prípravou 20. vydania Mental Measurement Yearbook, tak sa mi jej hned' aj dostalo. Získala som prístup na server a na mojom stole sa začali objavovat' recenzie po editácii. Mojou úlohou bolo zmeny zapracovávat’ do elektronickej podoby a dokumenty ešte raz kontrolovat'. Ku koncu prípravy knihy som mala potom na starosti prípravu všetkých menných registrov.

Bolo vel'mi zaujímavé sledovat' vznik takej vel'kej publikácie, akou je Mental Measurement Yearbook. Recenzie chodili skôr po vlnách než priebežne a po obsahových a odborných kontrolách sa všetky zbiehali u hlavnej editorky. V jednom momente som spočítala, že ak máme cez 200 testov, z každého 2 recenzie a každá má priemerne 10 strán, editorka prečíta a opraví približne 4000 strán textu. Ja som z toho zistenia bola ohromená, ona mierne zhrozená.

Celá táto vel’mi potrebná práca vzniká niekde v pivnici Univerzity v Nebraske, kde pár akademikov zasväcuje svoj život odkazu Oscara Burosa a jeho ženy Luelly. Boli to práve oni, kto si v tridsiatych rokoch minulého storočia začali uvedomovat' potrebu akejsi „ochrany spotrebitel'a“ pre užívatel'ov testov. V snahe o zvyšovanie kvality komerčných testov vydali prvých 9 ročeniek svojpomocne v pivnici vlastného domu a celý svoj život zasvätili snahe o zvyšovanie diagnostickej gramotnosti užívatel'ov testov i širokej verejnosti. 
Oscar Buros sa vysnívaného centra pre testovanie nedožil. Za svoj život nebol schopný zaistit' potrebné financie na jeho založenie. Luella sa však nevzdala a prostriedky hl'adala po celých Spojených štátoch až do roku 1978, kým im umožnila Univerzita v Nebraske v Lincolne premiestnit' ich rozsiahly archív testov na pôdu univerzity, kde v roku 1994 vzniklo Centrum pre Testovanie Oscara a Luelly Burosovcov v podobe, v akej existuje dodnes.

Zamestnanci Burosovho centra dodnes nesú ich odkaz. V dobe, ked' sa za valídne meracie nástroje vydáva kde-čo, je ich publikačná činnost', zvyšovanie diagnostickej gramotnosti a psychometrické poradenstvo možno nedocenenou, no vel'mi potrebnou prácou. A nám nezostáva, než byt' vd'ační za ich zápal a nadšenie, ktoré vkladajú do svojej práce, a ktoré sa odrazilo aj v poslednom, 20. vydaní Mental Measurement Yearbook.

\section{Shoshana Chovan (2017): Cornfield Psychometrics: Scholarship in the Buros Center}

The article is a short report from an internship at the Buros Center for Testing at the University of Nebraska-Lincoln. The introduction outlines the focus of the Buros Center and its publishing activity, with more detailed descriptions of individual publications. The main part of the article talks about the personal experience with working at the centre during an exchange program at the University of Nebraska and illustrates the work of a student worker. The article further describes the help with preparing the Mental Measurement Yearbook and in the end of this article summarizes the history of Buros Center and highlights its contribution to psychometrics. 